ORIGINAL ARTICLE

\title{
What is the long term outcome for children who fail to thrive? A systematic review
}

\author{
M C J Rudolf, S Logan
}

See end of article for authors' affiliations

\section{Correspondence to:}

Prof. M C J Rudolf, Leeds University and East Leeds Primary Care Trust, Belmont House, 3-5 Belmont Grove, Leeds LS2 9DE, UK; Mary.Rudolf@ Leedsth.nhs.uk

Accepted 24 April 2005 Published Online First 12 May 2005
Aims: To ascertain the long term outcomes in children diagnosed as having failure to thrive (FTT).
Methods: Systematic review of cohort studies. Medline, Psychinfo, Embase, Cinahl, Web of Science, Cochrane, and DARE databases were searched for potentially relevant studies. Inclusion criteria: cohort studies or randomised controlled trials in children $<2$ years old with failure to thrive defined as weight $<10$ th centile or lower centile and/or weight velocity $<10$ th centile, with growth, development, or behaviour measured at 3 years of age or older.

Results: Thirteen studies met the inclusion criteria; eight included a comparison group, of which five included children identified in community settings. Two were randomised controlled trials. Attrition rates were 10-30\%. Data from population based studies with comparison groups and which reported comparable outcomes in an appropriate form were pooled in a random effects meta-analysis. Four studies report IQ scores at follow up and the pooled standardised mean difference was $-0.22(95 \% \mathrm{Cl}-0.41$ to $-0.03)$. Two studies reported growth data as standard deviation scores. Their pooled weighted mean difference for weight was -1.24 SDS $(95 \% \mathrm{Cl}-2.00$ to -0.48$)$, and for height -0.87 SDS $(95 \% \mathrm{Cl}$ -1.47 to -0.28$)$. No studies corrected for parental height, but two reported that parents of index children were shorter.

Conclusions: The IQ difference (equivalent to $\sim 3 \mathrm{IQ}$ points) is of questionable clinical significance. The height and weight differences are larger, but few children were below the 3rd centile at follow up. It is unclear to what extent observed differences reflect causal relations or confounding due to other variables. In the light of these results the aggressive approach to identification and management of failure to thrive needs reassessing.
$M$ ost child health surveillance programmes both in the West and in poor countries include the regular weighing of infants and young children, with the aim of identifying those children who are growing inappropriately slowly. A variety of cut-off points for action are used, including weight below a particular centile (which ranges from $<10$ th to $<0.4$ th centile) or crossing more than a certain number of centiles. Recently it has been argued that clinicians should use the new charts which identify the slowest growing children while correcting for regression to the mean. ${ }^{1}$

A small number of children who are identified in this way will be diagnosed as having an organic illness, but over $90 \%$ will be labelled as having non-organic failure to thrive. ${ }^{2} \mathrm{~A}$ number of explanations have been advanced for this phenomenon of poor growth in early life in the absence of organic disease and in the presence of adequate supplies of food. Child abuse, ${ }^{3}$ oro-motor coordination leading to feeding difficulties, ${ }^{45}$ and inadequate parenting ${ }^{6}$ have all been implicated, and there is a widespread assumption that this early poor growth has significant long term effects on children's growth and development.

A variety of approaches to treatment of failure to thrive have been developed, but there is inconsistent evidence that these improve outcome. ${ }^{7-9}$ There is furthermore a clear potential for harm in this situation: failure to thrive is often a pejorative diagnosis, and may instil significant anxiety and feelings of lack of competence within the family. ${ }^{10}$

Given that there is currently little good evidence from randomised controlled trials that interventions are beneficial in failure to thrive, along with the lack of high quality studies on the effects of growth monitoring programmes on children's health, ${ }^{11}$ we aimed to systematically review prognostic studies of children diagnosed as having failure to thrive. We attempted to identify all cohorts of children labelled as having failure to thrive, however diagnosed, that reported measures of growth or psychomotor development at 3 years of age or later, regardless of what interventions were used.

\section{METHODS}

\section{Search strategy}

Medline, Cinahl, Psychinfo, Web of Science, and Embase databases were searched for cohort studies using the key terms failure to thrive, weight faltering, growth faltering with appropriate synonyms, and mis-spellings, combined with methodological terms including risk factors, prognosis, cohort studies, and outcomes. Randomised controlled trials were also identified for data relating to long term follow up of children in these studies (for this purpose the Cochrane Controlled Trials Register and DARE libraries were also searched). A full search strategy is available from MCJR.

Titles and abstracts identified by electronic searches were examined on screen to select potentially relevant studies. In addition, reference lists of identified studies and review articles were examined. Experts in the field were contacted for unpublished data.

\section{Inclusion criteria}

Studies identified as potentially relevant by the searches were reviewed by the authors against the following inclusion criteria:

- Population: Children identified as failing to thrive (defined as weight below the 10th or a lower centile, and/or a 
Table 1 Details of studies with a comparison group

\begin{tabular}{|c|c|c|c|c|c|c|c|}
\hline $\begin{array}{l}\text { First } \\
\text { author }\end{array}$ & Population & Definition of FTT & $\begin{array}{l}\text { Duration of } \\
\text { follow up }\end{array}$ & $\begin{array}{l}\text { Adequacy of } \\
\text { follow up }\end{array}$ & Controls & $\begin{array}{l}\text { Blinding at } \\
\text { assessment }\end{array}$ & $\begin{array}{l}\text { Potential confounders } \\
\text { reported in the study }\end{array}$ \\
\hline \multicolumn{8}{|c|}{ Population based studies } \\
\hline $\begin{array}{l}\text { Mitchell, } \\
1980^{12}\end{array}$ & $\begin{array}{l}19 \text { of } 30 \text { children with } \\
\text { history of FTT prior to } \\
24 \text { months of age in a } \\
\text { primary care clinic of } \\
312 \text { identified by } \\
\text { review of notes }\end{array}$ & $\begin{array}{l}<80 \% \text { normal } \\
\text { wt, or FTT cited } \\
\text { on the problem } \\
\text { list }\end{array}$ & At $3-6$ years & $\begin{array}{l}12 \text { of } 19 \\
\text { cases } 16 \\
\text { of } 19 \\
\text { controls }\end{array}$ & $\begin{array}{l}\text { Controls matched at } \\
\text { inception for age, } \\
\text { maternal age, marital } \\
\text { status, and family } \\
\text { problems }\end{array}$ & $\begin{array}{l}\text { Blinded for } \\
\text { McCarthy Scale } \\
\text { and behavioural } \\
\text { questionnaire but } \\
\text { not growth }\end{array}$ & $\begin{array}{l}\text { Life events score, sex, } \\
\text { mother's education, FTT }\end{array}$ \\
\hline $\begin{array}{l}\text { Corbett, } \\
1996^{13}\end{array}$ & $\begin{array}{l}52 \text { children identified } \\
\text { as FTा by child health } \\
\text { surveillance from } 306 \\
\text { eligible children } \\
\text { registered in } 2 \text { clinics }\end{array}$ & $\begin{array}{l}\text { A fall of } 2 \text { centile } \\
\text { lines for weight, } \\
\text { sustained for }>1 \\
\text { month }\end{array}$ & 5 years later & $\begin{array}{l}48 \text { of } 52 \\
(89 \%) \text { cases } \\
\text { and } 46 \text { of } \\
52(88 \%) \\
\text { controls }\end{array}$ & $\begin{array}{l}\text { Next child on clinic } \\
\text { register of same } \\
\text { age and sex }\end{array}$ & $\begin{array}{l}\text { Psychologists } \\
\text { blind to child's } \\
\text { status }\end{array}$ & $\begin{array}{l}\text { No control for } \\
\text { confounders }\end{array}$ \\
\hline $\begin{array}{l}\text { Drewett, } \\
1999^{14}\end{array}$ & $\begin{array}{l}136 \text { children with FTT } \\
\text { identified from a birth } \\
\text { cohort of } 3418\end{array}$ & $\begin{array}{l}\text { Thrive index }<5 \% \\
\text { on } 2 \text { or more } \\
\text { occasions between } \\
\text { ages 3-18 mth }\end{array}$ & At 7-9 years & $\begin{array}{l}\text { IQ testing: } \\
79 \% \text { cases, } \\
87 \% \text { controls } \\
\text { Growth } \\
\text { measures: } \\
82 \% \text { cases, } \\
91 \% \text { controls }\end{array}$ & $\begin{array}{l}\text { Selected from cohort } \\
\text { for normal growth and } \\
\text { matched for age and } \\
\text { residential area }\end{array}$ & $\begin{array}{l}\text { Psychologists } \\
\text { blind to child's } \\
\text { status }\end{array}$ & $\begin{array}{l}\text { Maternal IQ, parental } \\
\text { height, organic disease, } \\
\text { maternal smoking, } \\
\text { breast feeding, family } \\
\text { size, birth order }\end{array}$ \\
\hline $\begin{array}{l}\text { Kerr, } \\
2000^{15}\end{array}$ & $\begin{array}{l}92 \text { children with FTT, } \\
\text { of } 193 \text { children enrolled } \\
\text { in a longitudinal study } \\
\text { of child development } \\
\text { and maltreatment }\end{array}$ & $\begin{array}{l}\text { Weight }<5 \text { th } \\
\text { centile Age } \\
<25 \mathrm{mth} \\
\text { Normal birth wt }\end{array}$ & At $6 y$ of age & Not clear & $\begin{array}{l}101 \text { children with } \\
\text { wt }>10 \% \text { matched } \\
\text { for age, race, sex, } \\
\text { and SES }\end{array}$ & No detail given & $\begin{array}{l}\text { Maltreatment as defined } \\
\text { by a Child Protective } \\
\text { Services Report for } \\
\text { neglect, sexual or } \\
\text { physical abuse, SES, } \\
\text { age, gender }\end{array}$ \\
\hline $\begin{array}{l}\text { Boddy, } \\
2000^{16}\end{array}$ & $\begin{array}{l}47 \text { children identified } \\
\text { as FT by the age of } \\
12 \text { months from a } \\
\text { cohort of } 2004 \text { births } \\
\text { in } 1986 \text { and still } \\
\text { resident in the area }\end{array}$ & $\begin{array}{l}\text { Weight at } 12 \mathrm{mth} \\
\text { at or }<3 \mathrm{rd} \text { centile } \\
\text { and sustained for } \\
\text { at least } 3 \mathrm{mth}\end{array}$ & At 6 years & $\begin{array}{l}\text { IQ testing: } \\
42 \text { of } 47 \\
\text { cases, } 42 \\
\text { of } 47 \\
\text { controls } \\
\text { Growth } \\
\text { measures: } \\
38 \text { cases, } \\
39 \text { controls }\end{array}$ & $\begin{array}{l}\text { Matched at inception } \\
\text { for birth wt, sex, } \\
\text { ethnicity, and } \\
\text { residential area }\end{array}$ & $\begin{array}{l}\text { Blinded for } \\
\text { growth, unclear } \\
\text { if blinded for } \\
\text { IQ testing }\end{array}$ & $\begin{array}{l}\text { Maternal height, } \\
\text { maternal } I Q \text {, changes in } \\
\text { social index }\end{array}$ \\
\hline \multicolumn{8}{|c|}{ Clinical sample based studies } \\
\hline $\begin{array}{l}\text { Singer, } \\
1984^{17}\end{array}$ & $\begin{array}{l}13 \text { babies hospitalised } \\
\text { at age } 5-9 \text { months } \\
\text { for FTT }\end{array}$ & Weight $<3 \%$ & At 3 years & $\begin{array}{l}\text { All } 13 \text { cases, } \\
9 \text { of } 13 \\
\text { organic FTा } \\
\text { and } 5 \text { of } 13 \\
\text { controls }\end{array}$ & $\begin{array}{l}\text { Selected at inception } \\
\text { from children attending } \\
\text { the emergency room, } \\
\text { but no details given. } \\
\text { At F/U the remaining } \\
\text { controls had higher BW, } \\
\text { gestational age and } \\
\text { parental education }\end{array}$ & $\begin{array}{l}\text { No details } \\
\text { given }\end{array}$ & Parental education \\
\hline $\begin{array}{l}\text { Drotar, } \\
1992^{18}\end{array}$ & $\begin{array}{l}68 \text { hospitalised infants } \\
\text { aged 1-9 months, } \\
\text { randomly assigned to } \\
3 \text { types of intervention }\end{array}$ & $\begin{array}{l}\text { Normal birth } \\
\text { weight } \\
\text { decreasing to } \\
\text { weight }<5 \text { th } \\
\text { centile Weight } \\
\text { gain demonstrated } \\
\text { in hospital }\end{array}$ & $\begin{array}{l}\text { Age } 42- \\
48 \mathrm{mth}\end{array}$ & 48 of 68 & $\begin{array}{l}47 \text { controls matched at } \\
\text { inception for age, sex, } \\
\text { ethnicity, social factors, } \\
\text { mother's education }\end{array}$ & $\begin{array}{l}\text { No comment } \\
\text { on blinding of } \\
\text { assessors }\end{array}$ & $\begin{array}{l}\text { Effect of treatment } \\
\text { group }\end{array}$ \\
\hline $\begin{array}{l}\text { Reif, } \\
1995^{19}\end{array}$ & $\begin{array}{l}86 \text { children diagnosed } \\
\text { with } \mathrm{FTT} \text { at }<2 \text { years } \\
\text { of age either as in or } \\
\text { outpatients }\end{array}$ & $\begin{array}{l}\text { Age }<2 \text { y, } \\
\text { weight, height } \\
<5 \text { th centile for } \\
\text { at least } 6 \mathrm{mth} \text {, } \\
\text { term infants }\end{array}$ & 5 years later & $\begin{array}{l}61 \text { of } 86 \\
\text { children }\end{array}$ & $\begin{array}{l}65 \text { controls matched at } \\
\text { assessment for age, sex, } \\
\text { social setting, ethnicity } \\
\text { (but birth wt and } \\
\text { maternal ht were higher) }\end{array}$ & $\begin{array}{l}\text { No comment } \\
\text { on blinding of } \\
\text { assessors }\end{array}$ & $\begin{array}{l}\text { Birth weight, severity of } \\
\text { growth delay, parental } \\
\text { heights, parental } \\
\text { education }\end{array}$ \\
\hline
\end{tabular}

reduction in weight gain velocity) in the first two years of life in either hospital or community settings

- Outcome: At least one outcome measured at the age of 3 years or older, relating to growth, psychomotor development, and/or behaviour

- Study design: Cohort studies with or without comparison groups or randomised controlled trials.

Studies were specifically excluded if all participants were children born of low birth weight $(<2.5 \mathrm{~kg})$, if they were conducted in countries where malnutrition is prevalent, or if they included children identified as failing to thrive after the age of 2 years.

\section{Data extraction}

Data extracted from the studies included case definition, selection of controls, attrition rate, length of follow up, and measures of weight, height, psychomotor development, or IQ and behaviour.

In addition, we recorded whether in those studies with a control group, the outcome assessors were blind to case status, and what attempts had been made to adjust results for potential confounding variables. 


\begin{tabular}{|c|c|c|c|c|}
\hline Author & Population & Definition of $\mathrm{FT}$ & $\begin{array}{l}\text { Duration of } \\
\text { follow up }\end{array}$ & Adequacy of follow up \\
\hline \multicolumn{5}{|c|}{ Population based studies } \\
\hline Hutcheson, $1997^{20}$ & $\begin{array}{l}130 \text { children who were recruited from } \\
\text { primary care clinics to participate in } \\
\text { an RCT of home intervention for FTT } \\
\text { for } 12 \text { months }\end{array}$ & $\begin{array}{l}\text { Age }<25 \mathrm{mth} \text { old with weight } \\
<5 \text { th centile and weight/height } \\
<10 \text { th centile }\end{array}$ & At age 4 years & $\begin{array}{l}74 \text { of } 116 \text { children who } \\
\text { completed the trial }\end{array}$ \\
\hline Wright, $1998^{\circ}$ & $\begin{array}{l}229 \text { children identified as FTT by child } \\
\text { health surveillance, and enrolled in RCT } \\
\text { of health visitor intervention for } 7-35 \text { months } \\
\text { (120 intervention, } 109 \text { non-intervention) }\end{array}$ & $\begin{array}{l}\text { Fall of } 1.26 \mathrm{SD} \text { in weight } \\
\text { using the thrive index method }\end{array}$ & At age $>3$ years & $\begin{array}{l}105 / 120 \text { for intervention, } 97 / \\
109 \text { for non-intervention }\end{array}$ \\
\hline \multicolumn{5}{|c|}{ Clinical sample based studies } \\
\hline Kristiansson, $1987^{2}$ & $\begin{array}{l}34 \text { babies aged 4-18 months who } \\
\text { had been hospitalised with NOFTT }\end{array}$ & Rate of wt gain $<-2 S D$ & At age 4 years & 34 of 34 children \\
\hline Drotar, $1988^{22}$ & $\begin{array}{l}88 \text { babies aged 1-9 mth hospitalised for } \\
\text { FT of whom } 80 \text { consented to participate } \\
\text { and were randomly allocated to } 3 \text { forms } \\
\text { of intervention }\end{array}$ & $\begin{array}{l}\text { Normal birth weight decreasing } \\
\text { to weight }<5 \text { th centile } \\
\text { Weight gain demonstrated in } \\
\text { hospital }\end{array}$ & At age $36 \mathrm{mth}$ & 59 of the 80 children \\
\hline Sturm, $1989^{23}$ & Same children as above & & & \\
\hline
\end{tabular}

\section{Data analysis}

The studies were grouped as follows:

- Population based studies which attempted to ascertain all cases meeting prespecified criteria

- Clinical samples where defined entry criteria were taken to identify children who were inpatients, outpatients, or community referred children.

They were further divided according to whether or not they included a comparison group of children without failure to thrive.
The study details and results were then tabulated within these groups.

Where population based studies included an appropriate comparison group and had comparable methods of outcome assessment and reported data in a usable form, we pooled the results using a random effects meta-analysis. For estimates of weight and height differences, we included only studies that reported standard deviation scores (that is, standardised for age) and their confidence intervals, and performed a pooled weighted mean difference. For measures of psychomotor development or IQ we included studies that used any

A

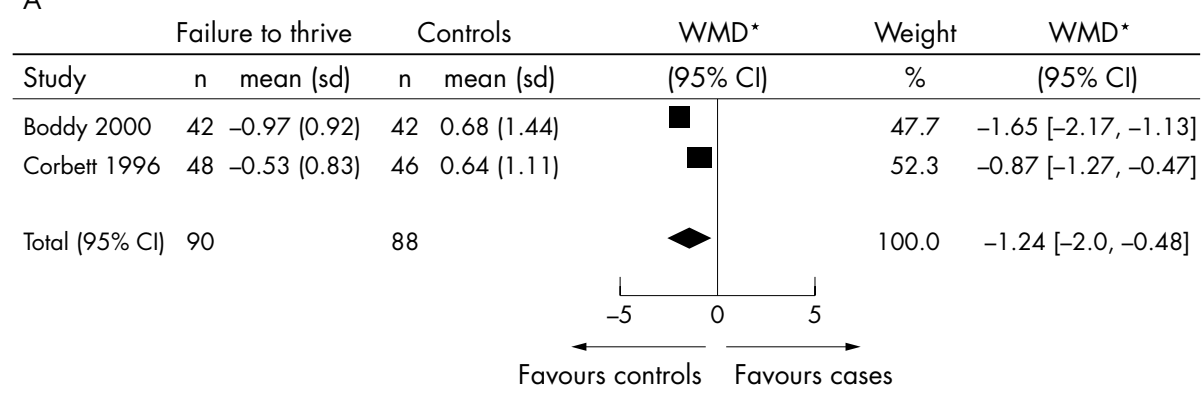

*WMD weighted mean difference

B

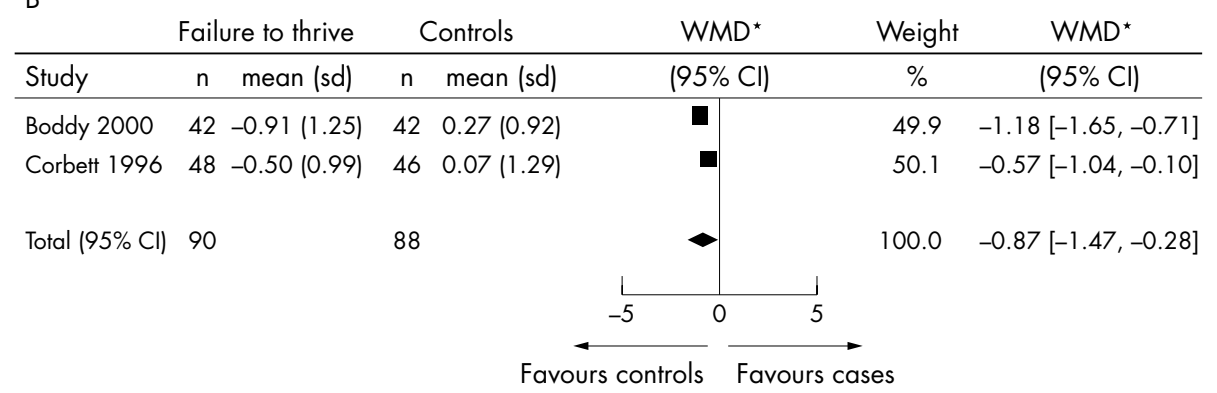

*WMD weighted mean difference

Figure 1 (A) Meta-analysis of weight SD scores in children who had experienced failure to thrive in infancy as compared with controls. (B) Metaanalysis of height SD scores in children who had experienced failure to thrive in infancy compared with controls. 
Table 3 Studies with a comparison group (data expressed as cases mean (SD) versus controls mean (SD))

\begin{tabular}{|c|c|c|c|c|}
\hline Author & Growth & Intellectual & Behavioural & Comments \\
\hline \multicolumn{5}{|c|}{ Population based studies } \\
\hline $\begin{array}{l}\text { Mitchell, } \\
1980^{12}\end{array}$ & $\begin{array}{l}\text { Weight: } 86 \% \text { normal } \\
\text { wt } v 96 \%, \mathrm{p}<0.05 \\
\text { Height: } 97 \% \text { normal } \\
\text { weight } v 99 \%\end{array}$ & $\begin{array}{l}\text { McCarthy Scale of Children's } \\
\text { Abilities: General Cognitive } \\
\text { Index } 87.5 \text { v } 92.5 \text { (sd12.9), } \\
p=\text { NS }\end{array}$ & $\begin{array}{l}\text { No behavioural deficits on } \\
\text { behavioural questionnaire }\end{array}$ & $\begin{array}{l}\text { No organic disease found. Life events } \\
\text { score was a predictor of } \mathrm{GCl}\end{array}$ \\
\hline $\begin{array}{l}\text { Corbett, } \\
1996^{13}\end{array}$ & $\begin{array}{l}\text { Mean weight } S D-0.53 \\
(0.83) \vee 0.34(1.11) \\
p<0.001 \text { Mean height SD: } \\
-0.5(0.99) \vee 0.07(1.29) \\
p=0.02\end{array}$ & $\begin{array}{l}\text { WISC-R (Wechsler Preschool } \\
\text { and Primary scale of } \\
\text { intelligence-revised) } \\
\text { IQ } 83.6(11.5) \vee 87 \text { (11.9) } \\
\text { (p=NS) }\end{array}$ & $\begin{array}{l}\text { No difference in number of } \\
\text { behaviour problems Child } \\
\text { Behaviour Checklist: } 33 \text { v } 34 \\
\text { Teachers' report form: } 23 \text { v } 14\end{array}$ & $\begin{array}{l}4 \text { in care; there was a relation between } \\
\text { severity of } F T \text { and } I Q, p=0.03\end{array}$ \\
\hline $\begin{array}{l}\text { Drewett, } \\
1999^{14}\end{array}$ & $\begin{array}{l}\text { Weight: 18th centile } v 56 \text { th } \\
\text { centile Height: } 21 \text { st centile } \\
v \text { 47th centile }\end{array}$ & $\begin{array}{l}\text { WISC IQ } 87.6(17.4) \vee 90.6 \\
(17.1) p=\text { NS Reading score } \\
93.5(16.2) \vee 94.5(15.6) \\
p=N S\end{array}$ & & $\begin{array}{l}\text { FIT paternal height significantly shorter } \\
\text { IQ difference reduced to a mean of } 1.7 \\
\text { when maternal IQ factored in } \\
\text { When parental height was taken into } \\
\text { consideration the height difference } \\
\text { between groups was marginally reduced }\end{array}$ \\
\hline \multicolumn{2}{|l|}{ Kerr, $2000^{15}$} & $\begin{array}{l}\text { WISC-R } 78(13.8) \text { to } 82(12.8) \\
v 83.6(12.4) \text { to } 84(12.5) \\
\text { range depending on presence } \\
\text { of maltreatment or not }\end{array}$ & $\begin{array}{l}\text { Child Behavior Checklist } \\
28.1(22.8) \text { to } 34.9(21.2) \\
\text { vs } 26.7(18.4) \text { to } 29(20.5) \\
\text { range depending on presence } \\
\text { of maltreatment or not } \\
\text { No increase in school behaviour } \\
\text { problems or maternal report of } \\
\text { problems unless maltreatment } \\
\text { also present }\end{array}$ & Overall $97 \%$ had wt for $h t>95 \%$ \\
\hline $\begin{array}{l}\text { Boddy, } \\
2000^{16}\end{array}$ & $\begin{array}{l}\text { Weight SD }-0.97(0.92) \\
v 0.68(1.44) \mathrm{p}<.001 \\
\text { Height SD }-0.91(1.25) \\
v 0.27(0.92), \mathrm{p}<0.001\end{array}$ & $\begin{array}{l}\text { McCarthy Scale of Children's } \\
\text { Abilities: General Cognitive } \\
\text { Index } 99.8 \pm 15.9 v \\
103.7 \pm 19.7, p=\text { NS }\end{array}$ & & $\begin{array}{l}\text { FTT maternal height significantly shorter } \\
\text { Strong correlation observed between } \\
\text { height and maternal height }\end{array}$ \\
\hline \multicolumn{5}{|c|}{ Clinical based samples } \\
\hline $\begin{array}{l}\text { Singer, } \\
1984^{17}\end{array}$ & & $\begin{array}{l}\text { Stanford-Binet Intelligence } \\
\text { Scale NOFTT } 78.6 \text { (13) v OFTT } \\
67.7 \text { (20) Controls } 97.4 \text { (25) }\end{array}$ & & $\begin{array}{l}\text { There was high attrition among controls } \\
\text { FTT parental education was shorter than } \\
\text { controls } \\
\text { Parental education related to: } I Q \text { at age } \\
3, p<0.02\end{array}$ \\
\hline $\begin{array}{l}\text { Drotar, } \\
1992^{18}\end{array}$ & & & $\begin{array}{l}\text { Inc. in parental report of } \\
\text { behavioural symptoms CBC } \\
58.5(10.7) \text { v } 53.2(12.7) \text {, } \\
p<0.005 \text { No. of children in } \\
\text { clinical behaviour problem } \\
\text { range } 15 \text { v } 10 \mathrm{p}=\mathrm{NS} \\
\text { Deficits in behavioural } \\
\text { organisation, ego control } \\
\text { and resiliency }\end{array}$ & \\
\hline Reif, $1995^{19}$ & $\begin{array}{l}\text { Weight centile: } 18.1 \\
(2.35) \text { v } 36(3.0), p<0.001 \\
\text { Height centile: } 21(2.8) \\
v 53.6(2.9), p<0.01\end{array}$ & $\begin{array}{l}\text { Learning difficulties } \\
18 \% \vee 3.1 \% \\
\text { Developmental delay } \\
11.5 \% \vee 0 \%\end{array}$ & $\begin{array}{l}\text { School problems and poor } \\
\text { achievement commoner }\end{array}$ & $\begin{array}{l}\text { Overall } 85 \% \text { were }>5 \% \text { for weight, } 90 \% \\
\text { were }>5 \% \text { for height } \\
\text { Maternal height and birth weight were } \\
\text { lower in cases than controls. Birth } \\
\text { weight, maternal height, and education } \\
\text { correlated with outcome }\end{array}$ \\
\hline
\end{tabular}

standardised scale and reported the group means and standard deviation. As these scales have different population means and standard deviations we calculated a pooled standardised mean difference.

\section{RESULTS}

Forty seven studies were identified from the searches as being of potential interest, ${ }^{9^{12-56}}$ of which $13^{912-23}$ met the inclusion criteria. Eight were cohort studies, ${ }^{12-17}{ }^{19}$ and five were randomised controlled trials. ${ }^{9} 18202223$ Of these, eight included a comparison group. ${ }^{12-19}$ Study characteristics are described in table 1 for those with a comparison group and in table 2 for those without. The main results are described in table 3 for studies with, and in table 4 for studies without a comparison group. All studies without a comparison group reported results suggesting that children with failure to thrive were shorter, lighter, and scored lower on measures of psychomotor development than population norms, with those recruited as clinical samples generally doing worse. Given the role of potential confounding variables, these studies were not analysed further.

\section{Quality of studies (tables 1 and 3)}

The definition of failure to thrive varied widely across studies with criteria ranging from weights $<5$ th centile to $<3$ rd centile, a fall down 2 centile lines, $<80 \%$ normal weight and a low thrive index. Attrition rates were 10-30\%.

In studies including a comparison group, most selected comparison groups at inception, and were matched for a variety of sociodemographic factors. Blinding was reported for developmental testing in all studies but none reported blinding of assessment of growth. 


\begin{tabular}{|c|c|c|c|}
\hline Author & Growth outcome & Intellectual outcome & Comments \\
\hline Hutcheson, $1997^{20}$ & $\begin{array}{l}\text { Intervention children: height SD } \\
-0.8(1.0) \text {, wt for ht } S D-1.7(0.6) \\
\text { Non-intervention children: height SD } \\
-1.0(1.1) \text {, wt for ht } S D-1.5(0.8)\end{array}$ & $\begin{array}{l}\text { Battelle Developmental Inventory } \\
71.6(17.9) \text { to } 84.9(13.2) \text { depending } \\
\text { on intervention status and degree of } \\
\text { maternal negativity }\end{array}$ & $\begin{array}{l}\text { Took into account demographic and maternal } \\
\text { psychological risk factors }\end{array}$ \\
\hline Wright, $1998^{\circ}$ & $\begin{array}{l}\text { Weight SD }-0.93 \text { (intervention) } v \\
-1.29 \text { (non-intervention), } p=0.04 \\
\text { Height } S D-0.79 \text { (intervention) } v \\
-1.13 \text { (non-intervention), } p=0.03\end{array}$ & & $\begin{array}{l}\text { Difference in height between controls and } \\
\text { intervention not significant when adjusted for } \\
\text { parental height }\end{array}$ \\
\hline Kristiansson, $1987^{21}$ & $\begin{array}{l}\text { Weight >-2SD } 21 \text { children (62\%) } \\
\text { Height >-2SD } 30(88 \%)\end{array}$ & & $\begin{array}{l}2 \text { children were in foster care and } 4 \text { had } \\
\text { social services support }\end{array}$ \\
\hline Drotar, $1988^{22}$ & & $\begin{array}{l}\text { Stanford Binet Intelligence score: } \\
\text { mean IQ } 85.4(15) \\
\text { In } 49 \% \text { the IQ was }>85 \text {, in } 14 \% \\
\text { it was }<70\end{array}$ & $\begin{array}{l}\text { IQ was related to maternal education, } \\
\text { income, and onset and duration of } F T\end{array}$ \\
\hline Sturm, $1989^{23}$ & $\begin{array}{l}\text { Weight for height: } 93.6 \text { (8.7) } \\
7 \% \text { were wasted } \\
15 \%<5 \% \text { for weight } \\
5 \%<5 \% \text { height }\end{array}$ & & \\
\hline
\end{tabular}

\section{Growth}

Growth data were presented in a variety of forms including standard deviation scores, mean centile position, \% normal weight/height, and weight for height, limiting the number of studies that could contribute to the pooled estimates. The data as presented also did not allow for analysis of differing severities of failure to thrive. All studies reported that children who had failure to thrive were lighter and shorter than comparison children at follow up..$^{12-14} 1619$ The majority of index children were however above the 3rd centile for both weight and height. Three studies reported that parental height was on average shorter for the cases..$^{14} 1619$

Two studies reported weight and height standard deviation scores (SDS $)^{13} 16$ and were pooled in a random effects metaanalysis. The pooled difference in weight was -1.2 SDS $(95 \%$ CI -2.0 to -0.5 ), and in height -0.9 SDS (95\% CI -1.5 to -0.3 ) (fig 1).

\section{Psychomotor development}

A variety of measures of psychomotor development and IQ were reported including the Wechsler Intelligence Scale for Children (WISC), McCarthy, Stanford Binet scales, or the Battelle Developmental Inventory. Measures were low overall, but no single study reported a statistically significant difference in IQ between cases and comparisons, ${ }^{12-17} 19$ although one clinic based study with a comparison group reported that $18 \%$ of the sample had learning difficulties as compared with only $3 \%$ of controls. ${ }^{19}$ One study commented that when they adjusted for maternal IQ they found a reduction in differences between the groups, ${ }^{14}$ and three studies reported a relation between parental education and child's IQ. ${ }^{17} 1922$

Four studies reported differences between group means and their standard deviations and were included in the metaanalysis. ${ }^{12-14} 16$ The pooled standardised mean difference in developmental quotient/intelligence quotient was - $0.2(95 \%$ CI 0.4 to 0.0 ) (fig 2). This difference equates to a mean difference of approximately 3 IQ points on the Wechsler Intelligence Scale for children.

\section{Behaviour}

Five studies with a comparison group reported assessments of behaviour. ${ }^{12} 13151819$ All used informal questionnaires to teachers or parents. Only one reported an increase in school problems. Three studies ${ }^{13} 1518$ reported results on the Child Behaviour Checklist, ${ }^{57}$ of which only one ${ }^{18}$ found a difference between the groups.

\section{DISCUSSION}

Where convincing evidence of the benefit of intervention is lacking, justification of efforts to identify and treat those with the "condition" must depend on the demonstration of

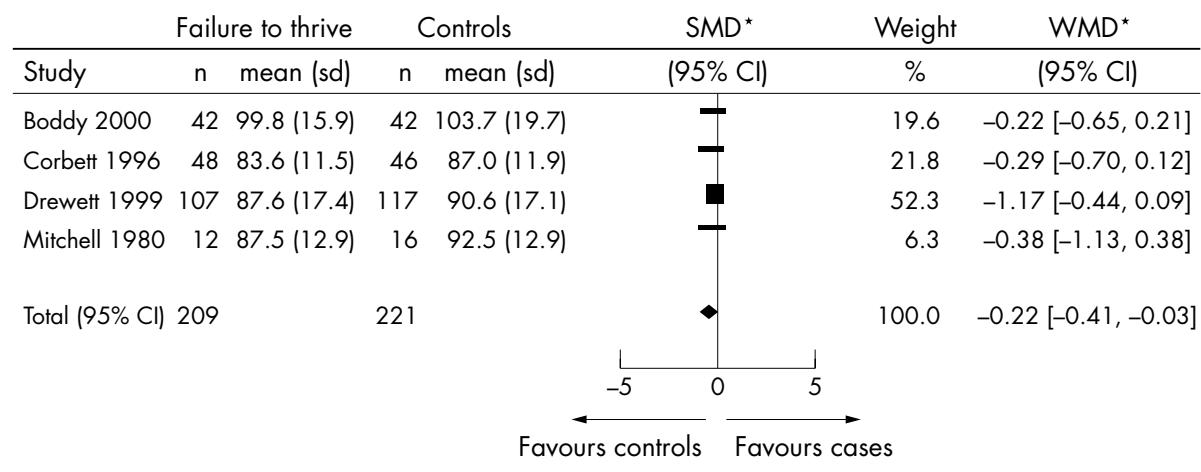

${ }^{\star} \mathrm{SMD}$ standardised mean difference

Figure 2 Meta-analysis of intellectual scores in children who had experienced failure to thrive in infancy compared with controls. 


\section{What is already known on this topic}

- Identification of failure to thrive by weight monitoring is a time honoured practice underpinned by the assumption that there are damaging consequences for growth and intellectual development

- Considerable stress and anxiety are often precipitated by health professionals when a child is found to be failing to thrive

deleterious effects on later outcome. The main finding of this review was the paucity of high quality follow up studies. The population studies which included comparison groups were small, none adjusted adequately for potential confounders (although a number matched on some important variables), and few reported data in a form which allowed inclusion in the meta-analyses. This relative lack of usable data reduces the precision of our estimates of the magnitude of the association between a diagnosis of failure to thrive and long term growth and cognitive development, and means that we cannot entirely exclude quite substantial effects. The heterogeneity of case definition further complicated interpretation, and the data were presented in a way that did not allow for analysis of differing levels of severity. Given this background, the pooled results need to be treated with caution.

The aim of systematic reviews is to provide an unbiased estimate of an association by including all studies meeting the inclusion criteria, whether or not they have been published. It is generally believed that location bias is likely to be a particular problem when dealing with observational studies. Although we used an exhaustive search strategy, including asking authors working in the field, we did not find unpublished studies and cannot be entirely certain that we have identified all relevant data.

Results of the included studies suggest that, on average, children identified as having failure to thrive in infancy will be shorter, lighter, and score less well on measures of psychomotor development than their peers. However, the clinical significance of these differences needs to be questioned for a number of reasons, both methodological and clinical.

Although a few of the studies attempted to control for potential confounding variables in their analyses, there is the strong likelihood that residual confounding remains. Some studies commented that "failure to thrive" parents were shorter $^{141619}$ and one study that parental education was of shorter duration, ${ }^{17}$ giving some credence to this suggestion.

On clinical grounds, the results also need to be interpreted with caution. Firstly, the pooled difference in IQ scores was relatively small and so of doubtful clinical significance. As regards growth, although the cases were on average smaller than the controls, few children were below the third centile on follow up. As no studies adjusted for parental height, and children were studied during the early primary school years, conclusions regarding final height would be premature. Lastly, some of the children may have had underlying genetic or pathophysiological reasons for poor growth which could affect growth both early in life and later, but should not lead one to conclude that the poor infant growth caused reduced growth in childhood.

Although severe and prolonged malnutrition clearly has profound long term effects on growth and psychomotor development, ${ }^{58}$ this review provides little good evidence that the growth pattern experienced by children included in the population based studies has serious deleterious effects on subsequent growth or psychomotor development although such an effect cannot be excluded. In most of the included

\section{What this study adds}

- Failure to thrive is associated with little reduction in $I Q$, but some reduction in childhood weight and height, although even this may be exaggerated as studies did not adjust for confounding factors such as parental height and IQ

- There is little evidence that identifying failure to thrive is predictive of damaging consequences for growth and intellectual development

studies, children from both FTT and control groups had relatively low scores on standardised tests of cognitive function at follow up compared to population norms. This suggests that these samples may have been largely drawn from relatively disadvantaged sections of the community.

This conclusion however does not mean that there is no benefit in identifying children who are growing poorly, particularly when there are associated developmental problems or clinical signs and symptoms. Clinical experience suggests that for a small number of children this is a route to the diagnosis of important, remediable organic conditions. ${ }^{2} \mathrm{~A}$ further small proportion of poorly growing children may do so as a result of neglect or the deliberate withholding of food, where poor growth can be an important marker for the need for intervention. Finally, this may be a route by which parents who are having difficulties in the management of feeding, or whose children have more general developmental problems, may access care. ${ }^{10}$

The challenge facing clinicians is how best to identify those children among the slowest growing who would benefit from investigation or intervention, without generating damaging anxiety in those that do not. Bearing in mind that there is currently little robust evidence from randomised controlled trials that intervention is associated with clear long term benefit, ${ }^{7-9}$ it is arguable whether screening can be justified, although it remains important that clinicians should respond appropriately to parental anxieties. Yet again, this illustrates the need for randomised controlled trials of interventions that pay careful attention to entry criteria and have adequate long term follow up.

\section{Authors' affiliations}

M C J Rudolf, Community Paediatrics, East Leeds Primary Care Trust and University of Leeds, Leeds, UK

S Logan, Peninsula Medical School, Exeter, UK

Competing interests: none

\section{REFERENCES}

1 Cole TJ. Conditional reference charts to assess weight gain in British infants. Arch Dis Child 1995;73:8-16.

2 Wright $C$. Identification and management of failure to thrive: a community perspective. Arch Dis Child 2000;82:5-9.

3 Hanks H, Hobbs C. Failure to thrive: a model for treatment. Baillieres Clin Paediatr 1993;1:101-19.

4 Ramsay M, Gisel EG, Boutry M. Nonorganic failure to thrive growth failure secondary to feeding skills disorder. Dev Med Child Neurol 1993;35:285-97.

5 Reilly SM, Skuse DH, Wolke D, et al. Oral motor dysfunction in children who fail to thrive: organic or non-organic? Dev Med Child Neurol 1996;41:115-22.

6 Iwaniec D, Herbert M, McNeish AS. Social work with failure to thrive children and their families. Part 1: psychosocial factors. British Journal of Social Work 1985; 15:243-59

7 Black MM, Dubowitz H, Hutcheson J, et al. A randomised clinical trial of home intervention for children with failure to thrive. Pediatrics 1995;95:807-14

8 Raynor P, Rudolf MCJ, Cooper K, et al. A randomised controlled trial of specialist health visitor intervention for failure to thrive. Arch Dis Child 1999;80:500-6.

9 Wright CM, Callum J, Birks E, et al. Effect of community based management in failure to thrive: randomised controlled trial. BMJ 1998;317:571-4. 
10 Underdown A. When feeding fails. The Children's Society, 2000.

11 Panpanich R, Garner P, Logan S. Is growth monitoring effective? A systematic review of trials. Arch Dis Child 2000;82:197-201.

12 Mitchell WG, Gorrell RW, Greenberg RA. Failure-to-thrive: a study in a primary care setting. epidemiology and follow-up. Pediatrics 1980;65:971-7.

13 Corbett SS, Drewett RF, Wright CM. Does a fall down a centile chart matter? The growth and developmental sequela of mild failure to thrive. Acta Paediatr 1996:85:1278-83.

14 Drewett RF, Corbett S, Wright CM. Cognitive and educational attainments at school age of children who failed to thrive in infancy: a population-based study. J Child Psychol Psychiatry 1999;40:551-61.

15 Kerr MA, Black MM, Krishnakumar A. Failure to thrive, maltreatment and the behavior and development of 6 year old children from low income, urban families: a cumulative risk model. Child Abuse Negl 2000;24:587-98.

16 Boddy J, Skuse D, Andrews B. The developmental sequelae of nonorganic failure to thrive. J Child Psychol Psychiatry 2000;41:1003-14.

17 Singer LT, Fagan JF. Cognitive development in the failure to thrive infant: a three year longitudinal study. J Pediatr Psychol 1984;9:363-83.

18 Drotar D, Sturm L. Personality development, problem solving, and behaviour problems among preschool children with early histories of nonorganic failureto-thrive: a controlled study. Dev Behav Paediatr 1992;13:266-73.

19 Reif S, Beler B, Villa Y, et al. Long-term follow-up and outcome of infants with non-organic failure to thrive. Isr J Med Sci 1995;31:483-9.

20 Hutcheson JJ, Black MM, Talley M, et al. Risk status and home intervention among children with failure to thrive: follow up at age 4. J Pediatr Psychol 1997;22:651-8.

21 Kristiansson B, Fallstrom SP. Growth at the age of 4 years subsequent to early failure to thrive. Child Abuse Negl 1987;11:35-40.

22 Drotar D, Sturm L. Prediction of intellectual development in young children with early histories of nonorganic failure-to- thrive. J Pediatr Psychol 1988;13:281-96.

23 Sturm L, Drotar D. Predication of weight for height following intervention in three-year-old children with early histories of nonorganic failure to thrive. Child Abuse Negl 1989;13:19-28.

24 Bullard DM, Glaser HH, Heagarty MC, et al. Failure to thrive in the "neglected" child. Am J Orthopsychiatry 1967;37:680-90.

25 Glaser HH, Heagarty MC, Bullard DM, et al. Physical and psychological development of children with early failure to thrive. J Pediatr 1968;73:690-8.

26 Shaheen E, Alexander D, Truskowsky $M$, et al. Failure to thrive-a retrospective profile. Clin Pediatr 1968;7:255-61.

27 White JL, Malcolm R, Roper K, et al. Psychosocial and developmental factors in failure to thrive: one-to-three year follow-up. Dev Behav Pediatr 1981;2:112-14.

28 Haynes CF, Cutler C, Gray J, et al. Hospitalized cases of nonorganic failure to thrive: the scope of the problem and short term lay health visitor intervention. Child Abuse Negl 1984;8:229-42.

29 Field $\mathbf{M}$. Follow-up developmental status of infants hospitalized for nonorganic failure to thrive. J Pediatr Psychol 1984;9:241-56.

30 Casey PH, Wortham B, Nebon JY. Management of FTT in a rural ambulatory setting. Clin Pediatr 1984;23:325-30.

31 Singer L. Long-term hospitalization of failure-to-thrive infants: developmental outcome at three years. Child Abuse Negl 1986;10:479-86.

32 Fryer GE. The efficacy of hospitalisation of nonorganic failure to thrive children: a meta-analysis. Child Abuse Negl 1988;12:375-81

33 Batchelor J, Kerslake A. Failure to find failure to thrive. London: Whiting and Bush, 1990.

34 Bithoney WG, McJunkin J, Michalek, et al. The effect of a multidisciplinary team approach on weight gain in nonorganic failure to thrive children. Dev Behav Paediatr 1991;12:254-8.
35 Skuse D, Pickles A, Wolke D, et al. Postnatal growth and mental development: evidence for a "sensitive period". J Child Psychol Psychiatry 1994;35:521-45

36 Bithoney WG, Van Sciver MM, Foster S, et al. Parental stress and growth outcome in growth-deficient children. Pediatrics 1995;96:707-1 1.

37 Wilensky DS, Ginsberg G, Altman M, et al. A community based study of failure to thrive in Israel. Arch Dis Child 1996;75:145-8.

38 Mackner LM, Starr RH, Black MM. The cumulative effect of neglect and failure to thrive on cognitive functioning. Child Abuse Negl 1997;21:691-700.

39 Elmer E, Gregg GS, Ellison P. Late results of the "failure to thrive" syndrome. Clin Pediatr 1969;8:584-9.

40 Hufton IW, Oates RK. Nonorganic failure to thrive: a long-term follow-up. Pediatrics 1977:59:73-7.

41 Holmes GL. Evaluation and prognosis in nonorganic failure to thrive. South Med J 1979;72:695-8.

42 Oates RK, Peacock A, Forrest D. Long-term effects of nonorganic failure to thrive. Pediatrics 1985;75:36-40

43 Dowdney L, Skuse D, Hepinstall E, et al. Growth retardation and developmental delay amongst inner-city children. Child Psychol Psychiatry 1987; 28:529-41.

44 Puckering C, Pickles A, Skuse D, et al. Mother-child interaction and the cognitive and behavioural development of four-year-old children with poor growth. J Child Psychol Psychiatry 1995:36:573-95.

45 Dowdney L, Skuse D, Morris K, et al. Short normal children and environmental disadvantage: a longitudinal study of growth and cognitive development from 4 to 11 years. J Child Psychol Psychiatry 1998;39:1017-29.

46 Iwaniec D, Sneddon H. Attachment style in adults who failed to thrive as children: outcomes of a 20 year follow-up study of factors influencing maintenance or change in attachment style. Br J Social Work 2001;31:179-95.

47 Dykman RA, Casey PH, Ackerman PT, et al. Behavioural and cognitive status in school aged children with a history of failure to thrive during early childhood. Clin Pediatr 2001;40:63-70.

48 Iwaniec D, Herbert M, McNeish AS. Social work with failure to thrive children and their families. Part II: Behavioural social work intervention. Br J Social Work 1985:15:375-89.

49 Pearce A, Finlay F. Children investigated for failure to thrive: where are they now? Professional Care of Mother and Child 1998;8:5-6

50 Black MM, Krishnamakur A. Predicting longitudinal growth curves of height and weight using ecological factors for children with and without early growth deficiency. J Nutr 1999;129:539-43S.

51 Kelleher KJ, Casey PH, Bradley RH, et al. Risk factors and outcomes for failure to thrive in low birth weight preterm infants. Pediatrics 1993;91:941-8.

52 Brooks Gunn J, McCarton CM, Casey PH, et al. Early intervention in low birth weight premature infants. JAMA 1994;272:1257-62.

53 Casey PH, Kelleher KJ, Bradley RH, et al. A multifaceted intervention for infants with failure to thrive. Arch Pediatr Adolesc Med 1994;148:1071-7.

54 Drotar D, Sturm L. Influences of the home environment of preschool children with early histories of nonorganic failure-to-thrive. Dev Behav Paediatr 1989:10:229-35.

55 Drotar D, Pallotta J, Eckerle D. A prospective study of family environments of children hospitalized for nonorganic failure-to-thrive. Dev Behav Paediatr 1994; 15:78-85.

56 Skuse DH, Gill D, Reilly S, et al. Failure to thrive and the risk of child abuse: a prospective population survey. J Med Screen 1995;2:145-9.

57 Achenbach T. Manual for the child behaviour checklist/4-18 and 1991 profile. Burlington: University of Vermont, 1991.

58 Waterlow J. Some aspects of childhood malnutrition as a public health problem. BMJ 1997;4:88-90. 